\title{
The Effects of Supplementary Cr3 (Chromium(III) Propionate Complex) on the Mineral Status in Healthy Female Rats
}

\author{
Halina Staniek ${ }^{1}$ (D) Zbigniew Krejpcio $^{1}$ \\ Received: 29 December 2016 / Accepted: 23 February 2017 / Published online: 10 March 2017 \\ (C) The Author(s) 2017. This article is published with open access at Springerlink.com
}

\begin{abstract}
More and more people use food supplements for various reasons, e.g. to prevent mineral deficiency and diseases (e.g. osteoporosis, diabetes, anaemia). Supplements containing $\mathrm{Cr}(\mathrm{III})$ are purchased primarily for weight loss and antidiabetic effects. The aim of this study was to evaluate the effects of supplementary $\mathrm{Cr} 3$ \{chromium(III) propionate complex, $\left.\left.\left[\mathrm{Cr}_{3} \mathrm{O}\left(\mathrm{O}_{2} \mathrm{CCH}_{2} \mathrm{CH}_{3}\right)_{6}\left(\mathrm{H}_{2} \mathrm{O}\right)_{3}\right] \mathrm{NO}_{3}\right)\right\}$ on the mineral status in female Wistar rats. The study was carried out on 30 female Wistar rats, divided into five groups (six animals in each): a control group and test groups fed $\mathrm{Cr} 3$ supplemented diets with 100, 200, 500 and $1000 \mathrm{mg} \mathrm{Cr} \cdot \mathrm{kg}^{-1}$ diet (equivalent to $10,20,50$ and $100 \mathrm{mg} \mathrm{Cr} \cdot \mathrm{kg}^{-1}$ body mass (b.m.) per day) given as $\mathrm{Cr} 3$ for 4 weeks. Supplementary $\mathrm{Cr} 3$ increased the $\mathrm{Cr}$ content in tissues in a dose-dependent manner. High dietary doses of $\mathrm{Cr} 3,20$ and $100 \mathrm{mg} \mathrm{Cr} \cdot \mathrm{kg}^{-1}$ b.m., increased the $\mathrm{Cu}$ content in the liver and spleen as well as the $\mathrm{Zn}$ content in the kidneys but decreased the liver Ca content. Doses of 50$100 \mathrm{mg} \mathrm{Cr} \cdot \mathrm{kg}^{-1}$ b.m. decreased the serum Fe concentration and the Fe content in the liver and kidneys. Supplementation with $\mathrm{Cr} 3$ at doses of 10 and $100 \mathrm{mg} \mathrm{Cr} \cdot \mathrm{kg}^{-1}$ b.m. did not affect the $\mathrm{Mg}$ content in the rats' tissues. In conclusion, high dietary doses of $\mathrm{Cr} 3$ (10 and $100 \mathrm{mg} \mathrm{Cr} \cdot \mathrm{kg}^{-1}$ b.m.) given for 4 weeks affected the mineral status of $\mathrm{Fe}, \mathrm{Zn}, \mathrm{Cu}$ and $\mathrm{Ca}$ in the tissues of healthy female Wistar rats.
\end{abstract}

Keywords Chromium(III) propionate $\cdot$ Rats $\cdot$ Mineral status

Halina Staniek

hali@up.poznan.pl

1 Department of Human Nutrition and Hygiene, Poznań University of Life Sciences, ul. Wojska Polskiego 31, 60-624 Poznań, Poland

\section{Introduction}

In recent years, chromium has been one of the most investigated dietary minerals. Chromium is a trace mineral that has received much attention as a dietary supplement because good dietary sources of chromium are scarce and the intake is usually low. Chromium(III) deficiency may contribute to carbohydrate metabolism disorder [1].

Many trials proved the positive effect of supplementary chromium(III) on fasting plasma glucose, lipid variables, especially in diabetic subjects [2-4]. For this reason, trivalent chromium has been postulated to be necessary for insulin efficacy in regulating the metabolism of carbohydrates, lipids and protein [5]. A number of chromium compounds can be considered as a perspective for metabolic syndrome treatment [6].

For over 50 years, chromium has generally been believed to be an essential trace element. However, the mechanism(s) of $\mathrm{Cr}$ action at the molecular level for this role and its essentiality have not been substantiated. Recent research has not supported the role of chromium [7].

In 2002, the Food and Nutrition Board of the US National Academy of Science set the Adequate Intake (AI) of chromium at $25 \mu \mathrm{g} \cdot \mathrm{day}^{-1}$ for adult women and $35 \mu \mathrm{g} \cdot \mathrm{day}^{-1}$ for men [8], which was lower than the previous recommended dietary intake of 50-200 $\mu \mathrm{g}$ per day. Recently, the EFSA panel found no evidence of beneficial effects associated with chromium intake in healthy subjects and concluded that setting the AI for chromium was not appropriate [5].

In general, the oral intake of chromium has low toxicity partially due to its poor absorption (about $0.5-2.0 \%$ ). However, different Cr(III) compounds have diverse rates of absorption [9]. Organic $\mathrm{Cr}$ (III) forms have greater bioavailability than inorganic ones. It is well known that the mineral intake at high doses has antagonistic effects on other elements [9]. 
Chromium is one of the best-selling mineral supplements in the USA [10]. Trivalent chromium, the form found in food and dietary supplements, is considered to be safe. Many organic chromium complexes, including chromium picolinate $\left[\mathrm{Cr}(\mathrm{Pic})_{3}\right]$, chromium nicotinate (NCB) $[11,12]$, chromium histidinate (CrHis) [13, 14], chromium complex of D-phenylalanine $\left[\mathrm{Cr}(\mathrm{D}-\mathrm{Phe})_{3}\right][15,16]$, chromium propionate complex (Cr3) [4, 17-19] and chromium glycinate complex (CrGly) [19], have been synthesised and demonstrated to be biologically effective. Different coordinate ligands of these organic chromium complexes exhibited different bioactive compounds [20].

For humans, a typical $\mathrm{Cr}$ intake is $20-45 \mu \mathrm{g}$ per day in the diet [21], while doses of supplements may contain 200-1000 $\mu \mathrm{g}$ Cr(III) $[1,22]$. These doses correspond to daily body weight-adjusted doses of $0.29-$ $0.64 \mu \mathrm{g} \mathrm{Cr}(\mathrm{III}) \cdot \mathrm{kg}^{-1}$ body mass (in the diet) and 2.86$14.3 \mu \mathrm{g} \mathrm{Cr}(\mathrm{III}) \cdot \mathrm{kg}^{-1}$ b.m. (in supplements) in an individual with an average weight of $70 \mathrm{~kg}$ [23].

Few studies have been designed to evaluate the effects of trivalent $\mathrm{Cr}$ supplementation on the content of $\mathrm{Cr}$ and other minerals in animal tissues. Chromium is distributed to various tissues of the body but appears to be most concentrated in the kidneys, liver and muscles [24]. Dietary Cr supplementation at high doses can potentially affect the mineral status due to possible interactions with other macro- and microelements at absorption, transport, metabolism, excretion and other levels [25]. In this case, the high supply of $\mathrm{Cr}$ (III) can affect the metabolism of other minerals in healthy rats. Therefore, the aim of this study was to evaluate the effects of high doses of chromium (III) complex with propionic acid, so-called $\mathrm{Cr} 3$ (100-1000 $\mathrm{mg} \mathrm{Cr} \cdot \mathrm{kg}^{-1}$ diet, equivalent to $10,20,50$ and $100 \mathrm{mg} \mathrm{Cr} / \mathrm{kg}$ b.m. per day) on the mineral status in healthy female rats.

\section{Material and Methods}

\section{Test Chemicals}

The chromium(III) complex with propionic acid in the form of nitrate salt (chemical formula $\left[\mathrm{Cr}_{3} \mathrm{O}\left(\mathrm{O}_{2} \mathrm{CCH}_{2} \mathrm{CH}_{3}\right)_{6}\left(\mathrm{H}_{2} \mathrm{O}\right)_{3}\right] \mathrm{NO}_{3}$ (Cr3) was synthesised in a laboratory at the Department of Product Ecology, Poznań University of Economics, Poland, according to the method described by Earnshaw et al. [26]. The Cr3 was found to contain $21 \%$ of elemental $\mathrm{Cr}$, determined by the AAS method (spectrometer AAS-3 with BC correction, Zeiss, Germany).

\section{Animals and Diets}

Thirty 10-week-old female Wistar rats were obtained from the Department of Toxicology, Poznań University of
Medical Sciences, Poland. The animals were housed in single cages, at controlled temperature, photoperiod and air humidity $\left(19-22{ }^{\circ} \mathrm{C}, 12\right.$-h light/dark cycle, $55-60 \%$ of ambient air humidity). After 5-day adaptation to laboratory conditions, the rats were divided into five equal groups (the control group and groups treated with $\mathrm{Cr} 3$ - six animals in each group, equal body weight of $180 \mathrm{~g}$ ). All the groups were fed a commercial diet for maintenance of adult rodents (Labofeed $H$ ), enriched with $0,100,200$, 500 and $1000 \mathrm{mg} \mathrm{Cr}(\mathrm{III}) / \mathrm{kg}$ of diet (ca. 0, 10, 20, 50 and $100 \mathrm{mg} \mathrm{Cr} / \mathrm{kg} \mathrm{b.m.} \mathrm{per} \mathrm{day)} \mathrm{given} \mathrm{as}$ $\left[\mathrm{Cr}_{3} \mathrm{O}\left(\mathrm{O}_{2} \mathrm{CCH}_{2} \mathrm{CH}_{3}\right)_{6}\left(\mathrm{H}_{2} \mathrm{O}\right)_{3}\right] \mathrm{NO}_{3}$ for 4 weeks. Table 1 shows the composition of the basic Labofeed $H$ diet. The $\mathrm{Cr}$ content in the basic diet (the control group) was $0.5 \pm 0.06 \mathrm{mg} \cdot \mathrm{kg}^{-1}$, while in the supplemented diets it was $107.5 \pm 6.5 \mathrm{mg} \cdot \mathrm{kg}^{-1}$ (A); $224.8 \pm 32.4 \mathrm{mg} \cdot \mathrm{kg}^{-1}$ (B); $535.5 \pm 26.22 \mathrm{mg} \cdot \mathrm{kg}^{-1}$ (C) and $1049.5 \pm 17.6 \mathrm{mg} \cdot \mathrm{kg}^{-1}$ (D), respectively. The diets were stored at $4{ }^{\circ} \mathrm{C}$. The rats were allowed free access to feed and distilled water throughout the whole experiment.

The feed intake was measured daily, while body weight gains were monitored weekly. At the end of the experiment, after 12-h starvation, the rats were euthanised by intraperitoneal injection of thiopental ( $40 \mathrm{mg} \cdot \mathrm{kg}^{-1}$ body mass). Blood was collected into tubes; tissue samples (liver, kidneys, heart, spleen, pancreas, ovaries) were collected, weighed and frozen. The experimental protocol was approved by the Local Bioethical Commission in Poznań (No. 12/2005).

\section{Laboratory Analyses}

The serum Fe concentration was determined with the colorimetric method by means of 2,4,6-tri(2-pyridylo)-5-triazine.

Diet and tissue samples for mineral analyses were digested with concentrated $65 \%$ spectra pure $\mathrm{HNO}_{3}$ (Merck) in a Microwave Digestion System (MARS-5, CEM, USA).

The concentration of copper $(\mathrm{Cu})$, zinc $(\mathrm{Zn})$, iron $(\mathrm{Fe})$, magnesium $(\mathrm{Mg})$ and calcium $(\mathrm{Ca})$ in mineralised samples was determined with the flame atomic absorption spectrometry method F-AAS (Zeiss AAS-3, with BC, Germany), while the concentration of $\mathrm{Cr}$ was measured using a graphite furnace atomic absorption spectrometer GF-AAS (AAS EA 5, with BC, Jenoptic, Germany). The accuracy of $\mathrm{Cu}, \mathrm{Zn}, \mathrm{Fe}, \mathrm{Mg}$ and $\mathrm{Ca}$ measurements was assured by simultaneous analysis of certified reference material (Pig Kidney BCR No. 186, Brussels), while the analysis of $\mathrm{Cr}$ was controlled using certified reference material (Virginia Tobacco Leaves CTA-VTL-2, Poland) (Table 2). The mean recoveries of certified levels (expressed as percentage of mean certified values) were as follows: $\mathrm{Cu}-103 \%, \mathrm{Zn}-101 \%, \mathrm{Fe}-97 \%, \mathrm{Mg}-$ $104 \%, \mathrm{Ca}-103 \%$ and $\mathrm{Cr}-102 \%$. 
Table 1 The composition of basic Labofeed $H$ diet in the experiment $($ mean $\pm \mathrm{SD})$

\begin{tabular}{llc}
\hline Component & Unit & Content \\
\hline Energy & $\mathrm{MJ} \cdot 100 \mathrm{~g}^{-1}$ & $1.69 \pm 0.03$ \\
Fat & $\%$ & $3.16 \pm 0.07$ \\
Protein & $\%$ & $24.10 \pm 0.21$ \\
Carbohydrates & $\%$ & 54.96 \\
Dry mass & $\%$ & $88.73 \pm 0.05$ \\
Ash & $\%$ & $6.51 \pm 0.11$ \\
$\mathrm{Ca}$ & $\mathrm{g} \cdot \mathrm{kg}^{-1}$ & $13.41 \pm 1.61$ \\
$\mathrm{Mg}$ & $\mathrm{g} \cdot \mathrm{kg}^{-1}$ & $2.24 \pm 0.06$ \\
$\mathrm{Fe}$ & $\mathrm{mg} \cdot \mathrm{kg}^{-1}$ & $239.49 \pm 46.34$ \\
$\mathrm{Zn}$ & $\mathrm{mg} \cdot \mathrm{kg}^{-1}$ & $133.19 \pm 42.31$ \\
$\mathrm{Cu}$ & $\mathrm{mg} \cdot \mathrm{kg}^{-1}$ & $20.42 \pm 2.91$ \\
\hline
\end{tabular}

\section{Statistical Analyses}

The data were presented as mean \pm SEM. The results were analysed using one-way analysis of variance (ANOVA/ MANOVA) and the Tukey's test to determine significant differences $(p<0.05)$. All calculations were done using Statistica ver. 7.0 software (StatSoft, Tulsa, USA).

\section{Results}

Figure 1 and Table 3 show the effects of $\mathrm{Cr} 3$ supplementation on the tissular content of $\mathrm{Cr}, \mathrm{Cu}, \mathrm{Zn}, \mathrm{Fe}, \mathrm{Mg}$ and $\mathrm{Ca}$ in healthy female rats. As expected, supplementary $\mathrm{Cr} 3$ increased the liver and kidney $\mathrm{Cr}$ levels in a dose-dependent manner (Fig. 1a). The addition of $\mathrm{Cr}$ (III) to the diet at a dose of $100 \mathrm{mg}$ of $\mathrm{Cr} \cdot \mathrm{kg}^{-1}$ did not significantly increase the liver $\mathrm{Cr}$ content $\left(3.91 \pm 0.24\right.$ vs. $2.96 \pm 0.18 \mu \mathrm{g} \cdot \mathrm{g}^{-1}$ dry mass $)$. However, in comparison with the control group $\left(2.96 \pm 0.18 \mu \mathrm{g} \cdot \mathrm{g}^{-1}\right.$ d.m.), the doses of 200,500 and $1000 \mathrm{mg}$ of $\mathrm{Cr}(\mathrm{III}) \cdot \mathrm{kg}^{-1}$ significantly increased the liver $\mathrm{Cr}$ level, by $78 \%\left(5.27 \pm 0.23 \mu \mathrm{g} \cdot \mathrm{g}^{-1} \mathrm{~d} . \mathrm{m}.\right), 242 \%$ $\left(10.13 \pm 0.21 \mu \mathrm{g} \cdot \mathrm{g}^{-1}\right.$ d.m. $)$ and $504 \%\left(17.88 \pm 0.93 \mu \mathrm{g} \cdot \mathrm{g}^{-1}\right.$ d.m.), respectively. Supplementary $\mathrm{Cr} 3$ at doses of 100 $1000 \mathrm{mg}$ of $\mathrm{Cr}^{-\mathrm{kg}^{-1}}$ increased the kidney $\mathrm{Cr}$ content by 229 , 272, 844 and $1541 \%$, respectively (Fig. 1b). All changes were statistically significant. Moreover, in the animals fed the diets containing 500 and $1000 \mathrm{mg} \mathrm{Cr}(\mathrm{III}) \cdot \mathrm{kg}^{-1}$, spleen $\mathrm{Cr}$ levels were markedly higher, by 44 and $106 \%$, respectively (Fig. 1c).

Supplementary $\mathrm{Cr} 3$ at doses of 100 to $1000 \mathrm{mg} \cdot \mathrm{Cr} \mathrm{kg}^{-1}$ had no effect on the kidney $\mathrm{Cu}$ content in the female rats. However, the dose of $200 \mathrm{mg} \mathrm{Cr}(\mathrm{III}) \cdot \mathrm{kg}^{-1}$ significantly increased the liver $\mathrm{Cu}$ level by $16 \%\left(27.15 \pm 0.70 \mu \mathrm{g} \cdot \mathrm{g}^{-1} \mathrm{~d}\right.$.m. $)$ as compared with the control rats $\left(23.42 \pm 0.70 \mu \mathrm{g} \cdot \mathrm{g}^{-1} \mathrm{~d} . \mathrm{m}\right.$.) High doses of $\mathrm{Cr}$ (III) (500 and $1000 \mathrm{mg} \cdot \mathrm{kg}^{-1}$ ) increased the spleen $\mathrm{Cu}$ content by $48 \%\left(14.90 \pm 0.52 \mu \mathrm{g} \cdot \mathrm{g}^{-1}\right.$ d.m. $)$ and $53 \%\left(15.43 \pm 0.57 \mu \mathrm{g} \cdot \mathrm{g}^{-1}\right.$ d.m.), respectively vs. control group $\left(10.10 \pm 0.70 \mu \mathrm{g} \cdot \mathrm{g}^{-1}\right.$ d.m.) (Table 3).

Supplementary $\mathrm{Cr} 3$ did not affect the liver and spleen $\mathrm{Zn}$ contents. However, in comparison with the control group $\left(110.1 \pm 4.9 \mu \mathrm{g} \cdot \mathrm{g}^{-1}\right.$ d.m.), the diets supplemented with 500 and $1000 \mathrm{mg} \mathrm{Cr}(\mathrm{III}) \cdot \mathrm{kg}^{-1}$ significantly increased the kidney $\mathrm{Zn}$ level, by $29 \%\left(141.7 \pm 5.5 \mu \mathrm{g} \cdot \mathrm{g}^{-1} \mathrm{~d}\right.$.m. $)$ and $21 \%$ $\left(132.8 \pm 3.6 \mu \mathrm{g} \cdot \mathrm{g}^{-1}\right.$ d.m.), respectively.

The effect of supplementary $\mathrm{Cr} 3$ on Fe metabolism was assessed on the basis of morphological and haematological blood indices, such as haemoglobin concentration $(\mathrm{Hb})$, haematocrit ratio (HCT), the number of erythrocytes in the blood (RBC), mean platelet volume (MPV), mean corpuscular volume (MCV), mean corpuscular haemoglobin concentration (MCHC), red cell distribution width (RDW) (the data were presented in our previous paper) [27], serum Fe concentration and tissular Fe content (liver, kidney and spleen) (Table 3). The haematological indices under analysis in the rats supplemented with $\mathrm{Cr} 3$ were not significantly different from the control rats [27]. However, the highest dose of $\mathrm{Cr}$ $1000 \mathrm{mg} \mathrm{kg}^{-1}$ (100 mg. $\mathrm{kg}^{-1}$ b.m.) decreased the serum $\mathrm{Fe}$ concentration by $28 \%$. As far as the tissular Fe levels are concerned, the $\mathrm{Cr}$ doses of 500 and $1000 \mathrm{mg} \cdot \mathrm{kg}^{-1}$ significantly reduced the liver Fe content by $20 \%\left(1002 \pm 58 \mu \mathrm{g} \cdot \mathrm{g}^{-1}\right.$ d.m.) and $21 \%\left(1020 \pm 54 \mu \mathrm{g} \cdot \mathrm{g}^{-1}\right.$ d.m.), respectively, and the
Table 2 The accuracy of the method of determination of elements (mean $\pm \mathrm{SD}$ )

\begin{tabular}{lllll}
\hline Element & $\begin{array}{l}\text { Number of samples } \\
(n)\end{array}$ & $\begin{array}{l}\text { Certified value } \\
\left(\mu \mathrm{g} \cdot \mathrm{g}^{-1}\right)\end{array}$ & $\begin{array}{l}\text { Analytical value } \\
\left(\mu \mathrm{g} \cdot \mathrm{g}^{-1}\right)\end{array}$ & $\begin{array}{l}\text { Method accuracy } \\
{[\% \text { certified value] }}\end{array}$ \\
\hline \multicolumn{5}{c}{} \\
$\mathrm{Ca}$ & 6 & Certified reference material Pig Kidney BCR No. 186 \\
$\mathrm{Mg}$ & 6 & $295 \pm 2$ & $291.13 \pm 7.46$ & 98.7 \\
$\mathrm{Fe}$ & 6 & $830 \pm 8$ & $843.80 \pm 11.25$ & 101.7 \\
$\mathrm{Zn}$ & 6 & $299 \pm 2$ & $295.96 \pm 11.53$ & 99.0 \\
$\mathrm{Cu}$ & 6 & $128 \pm 3$ & $123.60 \pm 1.52$ & 96.6 \\
$\mathrm{Cr}$ & 6 & $31.9 \pm 0.4$ & $31.87 \pm 0.20$ & 99.9 \\
\hline
\end{tabular}


Fig. 1 Chromium contents in tissues after $\mathrm{Cr} 3$ supplementation at doses 100, 200, 500 and $1000 \mathrm{mg} \mathrm{Cr} \cdot \mathrm{kg}^{-1}$ diet for 4 weeks in female Wistar rats, a liver, $\mathbf{b}$ kidney, c spleen, (microgram per gram dry mass). Different letter superscripts indicate statistically significant differences at $p<0.05$.

Control group, $A$-group

supplemented with

$100 \mathrm{mg} \mathrm{Cr}(\mathrm{III}) \cdot \mathrm{kg}^{-1}$ diet, $B$ -

group supplemented with

$200 \mathrm{mg} \mathrm{Cr}(\mathrm{III}) \cdot \mathrm{kg}^{-1}$ diet, $C$ -

group supplemented with

$500 \mathrm{mg} \mathrm{Cr}(\mathrm{III}) \cdot \mathrm{kg}^{-1}$ diet and $D$

group supplemented with

$1000 \mathrm{mg} \mathrm{Cr}(\mathrm{III}) \cdot \mathrm{kg}^{-1}$ diet
A)

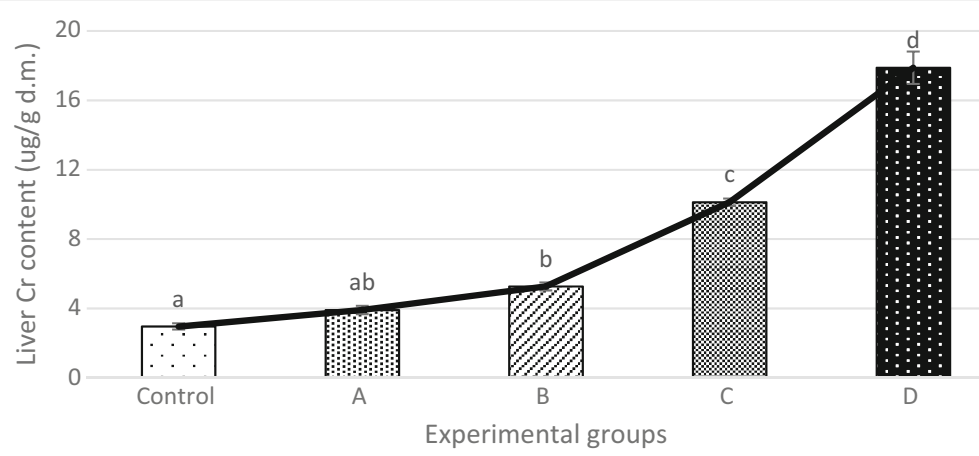

B)

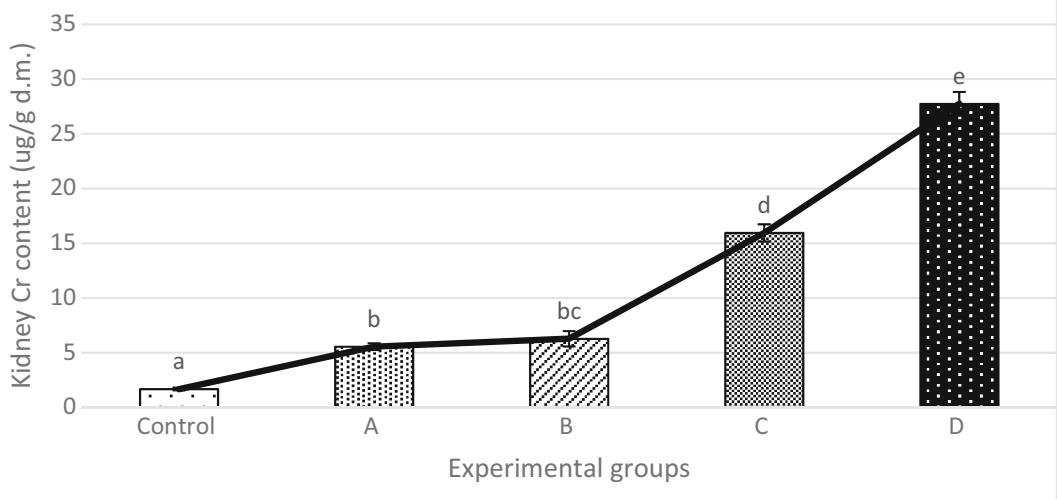

C)

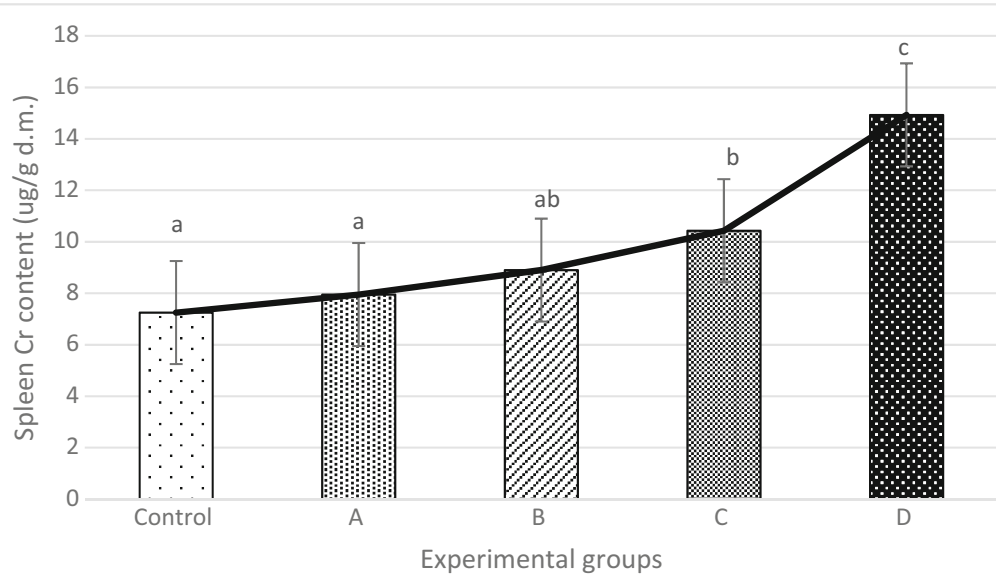

There were no significant differences in the tissular $\mathrm{Mg}$ levels of healthy female rats fed diets with $\mathrm{Cr} 3$ at doses of 100 to $1000 \mathrm{mg}$ of $\mathrm{Cr} \cdot \mathrm{kg}^{-1}$. kidney Fe level by $18 \%\left(402 \pm 19 \mu \mathrm{g} \cdot \mathrm{g}^{-1}\right.$ d.m.) and $24 \%$ $\left(375 \pm 13 \mu \mathrm{g} \cdot \mathrm{g}^{-1}\right.$ d.m.), respectively. No effects on the spleen Fe content were noted. 
Table 3 The effect of supplementary $\mathrm{Cr} 3$ on the mineral status in healthy female rats (mean $\pm \mathrm{SEM}$ )

\begin{tabular}{|c|c|c|c|c|c|}
\hline \multirow[t]{2}{*}{ Index } & \multicolumn{5}{|c|}{ Experimental groups } \\
\hline & $\begin{array}{l}\text { Control } \\
\left(1 \mathrm{mg} \cdot \mathrm{kg}^{-1}\right)\end{array}$ & $\begin{array}{l}\text { A } \\
\left(100 \mathrm{mg} \cdot \mathrm{kg}^{-1}\right)\end{array}$ & $\begin{array}{l}\text { B } \\
\left(200 \mathrm{mg} \cdot \mathrm{kg}^{-1}\right)\end{array}$ & $\begin{array}{l}\mathrm{C} \\
\left(500 \mathrm{mg} \cdot \mathrm{kg}^{-1}\right)\end{array}$ & $\begin{array}{l}\text { D } \\
\left(1000 \mathrm{mg} \cdot \mathrm{kg}^{-1}\right)\end{array}$ \\
\hline & \multicolumn{5}{|c|}{ Cr status } \\
\hline Liver $\mathrm{Cr}$ content ( $\mu \mathrm{g} \cdot \mathrm{g}^{-1}$ d.m.) & $2.96 \pm 0.18^{\mathrm{a}}$ & $3.91 \pm 0.24^{\mathrm{ab}}$ & $5.27 \pm 0.23^{\mathrm{b}}$ & $10.13 \pm 0.21^{\mathrm{c}}$ & $17.88 \pm 0.93^{\mathrm{d}}$ \\
\hline Kidney $\mathrm{Cr}$ content $\left(\mu \mathrm{g} \cdot \mathrm{g}^{-1}\right.$ d.m.) & $1.69 \pm 0.12^{\mathrm{a}}$ & $5.56 \pm 0.31^{\mathrm{b}}$ & $6.28 \pm 0.71^{\mathrm{bc}}$ & $15.95 \pm 0.79^{\mathrm{d}}$ & $27.74 \pm 1.09^{\mathrm{e}}$ \\
\hline Spleen $\mathrm{Cr}$ content ( $\left.\mu \mathrm{g} \cdot \mathrm{g}^{-1} \mathrm{~d} . \mathrm{m}.\right)$ & $7.25 \pm 0.44^{\mathrm{a}}$ & \multicolumn{2}{|r|}{$\mathrm{Cu}$ status } & $10.43 \pm 0.47^{\mathrm{b}}$ & $14.93 \pm 0.79^{\mathrm{c}}$ \\
\hline Liver $\mathrm{Cu}$ content ( $\left.\mu \mathrm{g} \cdot \mathrm{g}^{-1} \mathrm{~d} . \mathrm{m}.\right)$ & $23.42 \pm 0.70^{\mathrm{a}}$ & $24.26 \pm 0.66^{\mathrm{ab}}$ & $27.15 \pm 0.70^{\mathrm{b}}$ & $24.22 \pm 0.77^{\mathrm{a}}$ & $24.04 \pm 0.66^{\mathrm{a}}$ \\
\hline Kidney $\mathrm{Cu}$ content $\left(\mu \mathrm{g} \cdot \mathrm{g}^{-1}\right.$ d.m. $)$ & $57.38 \pm 5.34$ & $52.09 \pm 2.08$ & $55.55 \pm 3.97$ & $58.83 \pm 2.79$ & $49.30 \pm 4.42$ \\
\hline Spleen $\mathrm{Cu}$ content $\left(\mu \mathrm{g} \cdot \mathrm{g}^{-1} \mathrm{~d} . \mathrm{m}.\right)$ & \multicolumn{4}{|c|}{ Zn status } & $15.43 \pm 0.57^{\mathrm{c}}$ \\
\hline Liver $\mathrm{Zn}$ content ( $\mu \mathrm{g} \cdot \mathrm{g}^{-1}$ d.m.) & $128.2 \pm 5.2$ & $122.3 \pm 6.0$ & $118.1 \pm 3.5$ & $129.7 \pm 3.0$ & $136.4 \pm 6.0$ \\
\hline Kidney $\mathrm{Zn}$ content $\left(\mu \mathrm{g} \cdot \mathrm{g}^{-1}\right.$ d.m.) & $110.1 \pm 4.9^{\mathrm{a}}$ & $120.2 \pm 3.1^{\mathrm{ab}}$ & $121.3 \pm 6.8^{\mathrm{abc}}$ & $141.7 \pm 5.5^{\mathrm{c}}$ & $132.8 \pm 3.6^{\mathrm{bc}}$ \\
\hline Spleen $\mathrm{Zn}$ content ( $\left.\mu \mathrm{g} \cdot \mathrm{g}^{-1} \mathrm{~d} . \mathrm{m}.\right)$ & $130.4 \pm 4.0$ & $118.7 \pm 4.6$ & $\begin{array}{r}126.1 \pm 3.8 \\
\text { Fe status }\end{array}$ & $122.0 \pm 5.4$ & $121.7 \pm 8.5$ \\
\hline Serum Fe concentration $\left(\mu \mathrm{g} \cdot \mathrm{dl}^{-1}\right)$ & $296 \pm 19^{b}$ & $248 \pm 10^{\mathrm{ab}}$ & $242 \pm 15^{\mathrm{ab}}$ & $246 \pm 15^{\mathrm{ab}}$ & $214 \pm 15^{\mathrm{a}}$ \\
\hline Liver Fe content ( $\mu \mathrm{g} \cdot \mathrm{g}^{-1}$ d.m.) & $1272 \pm 42^{\mathrm{b}}$ & $1202 \pm 44^{\mathrm{ab}}$ & $1163 \pm 39^{\mathrm{ab}}$ & $1002 \pm 58^{\mathrm{a}}$ & $1020 \pm 54^{\mathrm{a}}$ \\
\hline Kidney Fe content ( $\mu \mathrm{g} \cdot \mathrm{g}^{-1}$ d.m.) & $490 \pm 21^{\mathrm{c}}$ & $460 \pm 20^{\mathrm{bc}}$ & $429 \pm 24^{\mathrm{abc}}$ & $402 \pm 19^{\mathrm{ab}}$ & $375 \pm 13^{\mathrm{a}}$ \\
\hline Spleen Fe content ( $\mu \mathrm{g} \cdot \mathrm{g}^{-1}$ d.m.) & $7364 \pm 554$ & $7592 \pm 484$ & $\begin{array}{r}7420 \pm 438 \\
\text { Mg status }\end{array}$ & $7241 \pm 354$ & $8672 \pm 615$ \\
\hline Liver $\mathrm{Mg}$ content $\left(\mu \mathrm{g} \cdot \mathrm{g}^{-1}\right.$ d.m.) & $851 \pm 33$ & $844 \pm 37$ & $801 \pm 30$ & $865 \pm 25$ & $868 \pm 29$ \\
\hline Kidney $\mathrm{Mg}$ content $\left(\mu \mathrm{g} \cdot \mathrm{g}^{-1} \mathrm{~d} . \mathrm{m}.\right)$ & $978 \pm 28$ & $980 \pm 20$ & $973 \pm 18$ & $1001 \pm 42$ & $979 \pm 47$ \\
\hline Spleen $\mathrm{Mg}$ content ( $\mu \mathrm{g} \cdot \mathrm{g}^{-1}$ d.m.) & $1078 \pm 42$ & $914 \pm 22$ & $\begin{array}{l}964 \pm 24 \\
\text { Ca status }\end{array}$ & $994 \pm 32$ & $994 \pm 55$ \\
\hline Liver Ca content ( $\mu \mathrm{g} \cdot \mathrm{g}^{-1}$ d.m.) & $49.8 \pm 1.4^{\mathrm{c}}$ & $43.2 \pm 1.6^{\mathrm{c}}$ & $25.6 \pm 3.1^{\mathrm{b}}$ & $23.0 \pm 1.0^{\mathrm{ab}}$ & $15.7 \pm 1.0^{\mathrm{a}}$ \\
\hline Kidney Ca content $\left(\mu \mathrm{g} \cdot \mathrm{g}^{-1} \mathrm{~d} . \mathrm{m}.\right)$ & $226 \pm 10$ & $253 \pm 14$ & $264 \pm 11$ & $267 \pm 11$ & $267 \pm 12$ \\
\hline Spleen Ca content ( $\left.\mu \mathrm{g} \cdot \mathrm{g}^{-1} \mathrm{~d} . \mathrm{m}.\right)$ & $547 \pm 52$ & $548 \pm 53$ & $519 \pm 51$ & $486 \pm 44$ & $367 \pm 38$ \\
\hline
\end{tabular}

The values in the same row that do not share the same superscript letter are significantly different $(P<0.05)$

Control control group, $A$ group supplemented with $100 \mathrm{mg} \mathrm{Cr(III) \cdot} \mathrm{kg}^{-1}$ diet, $B$ group supplemented with $200 \mathrm{mg} \mathrm{Cr(III) \cdot} \mathrm{kg}^{-1}$ diet, $C$ group supplemented with $500 \mathrm{mg} \mathrm{Cr}(\mathrm{III}) \cdot \mathrm{kg}^{-1}$ diet, $D$ group supplemented with $1000 \mathrm{mg} \mathrm{Cr}(\mathrm{III}) \cdot \mathrm{kg}^{-1}$ diet, $d . m$. dry mass, $d l$ decilitre

The kidney and spleen Ca levels in the groups supplemented with $\mathrm{Cr} 3$ were not different than in the control group. However, supplementary $\mathrm{Cr} 3$ decreased the liver $\mathrm{Ca}$ level in a dose-dependent manner. The addition of $\mathrm{Cr}$ (III) at a dose of $100 \mathrm{mg} \cdot \mathrm{kg}^{-1}$ to the diet had no effect. However, in comparison with the control group $\left(49.8 \pm 1.4 \mu \mathrm{g} \cdot \mathrm{g}^{-1} \mathrm{~d} . \mathrm{m}\right.$.), the doses of 200,500 and $1000 \mathrm{mg} \cdot \mathrm{kg}^{-1}$ significantly increased the liver Ca level, by 49, 59 and 68\%, respectively.

\section{Discussion}

Our previous studies showed that $\mathrm{Cr} 3$ was a relatively safe compound [18, 28, 29].

Publications concerning $\mathrm{Cr}$ are related to the transport, distribution and bioactivities of this element from various $\mathrm{Cr}$ compounds in different biological models.
The effects of the nutritional supplement $\mathrm{Cr} 3$ on healthy rats and rat models of insulin resistance and type 1 and 2 diabetes have been examined [4, 17, 27, 30-34]. Some reports have shown that chromium(III) has beneficial effects for the organism with disturbances of glucose and lipid metabolism $[4,17,31]$. However, data from the experiments conducted in healthy individuals quite often explicitly show lack of any favourable impact of $\mathrm{Cr}$ (III) on carbohydrates/lipid metabolism [27, 32-34]. Our study [27] showed no effect of $\mathrm{Cr} 3$ at doses 100-1000 mg of Cr(III) $\mathrm{kg}^{-1}$ diet on serum glucose, total cholesterol, LDL-cholesterol, and HDL-cholesterol concentration (Table 4).

Bennett et al. [34] found that $\mathrm{Cr} 3$ at doses of 1,5 and $10 \mathrm{mg} \mathrm{Cr} \cdot \mathrm{kg}^{-1}$ lowered plasma insulin, leptin and triglycerides concentrations but had no effect on plasma HDL, LDL and total cholesterol after 10 weeks of treatment in male SpragueDawley rats. Healthy Sprague-Dawley rats treated daily with 
$20 \mu \mathrm{g} \cdot \mathrm{kg}^{-1}$ body mass as $\mathrm{Cr} 3$ intravenously for 12 weeks had lower blood plasma insulin, total cholesterol, LDL, HDL and triglycerides but not glucose levels [31]. The data obtained by Herring et al. [32] strongly suggest that long-term (15-month) $\mathrm{Cr} 3$ supplementation does not significantly affect metabolic responses in blood glucose concentration to glucose and insulin in male Wistar rats consuming a normal diet or high-fat, high-carbohydrate cafeteria-style diet. Also Król et al. [33] confirmed that supplementary $\mathrm{Cr} 3$, given in the dosages 0.6 and $3 \mathrm{mg} \cdot \mathrm{kg}^{-1}$ b.m. for 8 weeks, did not affect serum glucose, insulin and HOMA-IR index and serum lipid indices, except TAG (tended to decrease) in rats fed high-fat diet.

Unfortunately, the molecular mechanism by which chromium affects glucose and lipid metabolism is still unclear. This turn leads to the hypothesis that chromium ion supplementation have been beneficial only in disorders of glucose and lipid metabolism [35]. Most of the available literature exploring the effects of chromium supplementation in rats have been shortterm studies [4, 25, 27-29, 36, 37]. Few have looked at the effect of long-term chromium supplementation [17, 31, 38, 39]. For the other roles of chromium in the body, we should use this supplement in a reasonable manner, being aware its possible side-effects.

However, there is little data on the influence of $\mathrm{Cr}$ on the mineral status in healthy individuals, particularly at pharmacological levels. Dietary supplementation with high doses of $\mathrm{Cr}$ (III) may disorder the status of other elements.

The accumulation of $\mathrm{Cr}$ in the liver and kidneys of rats receiving supplementary $\mathrm{Cr} 3$ was observed, but the results depended on the chemical form and dose of $\mathrm{Cr}$. The $\mathrm{Cr}$ content in the liver, kidneys and spleen was found to increase in a manner dependent on the supply of $\mathrm{Cr}$ (III) in the diet. Other authors found similar relationships between the intake of $\mathrm{Cr}(\mathrm{III})$ and its concentration in the liver and kidney tissues in normal rats [40-42], in rats with diabetes mellitus type 1 and 2 [17, 30], in pig [43] and in quails [44].

Lindemann et al. [45] demonstrated differences between $\mathrm{Cr}$ sources in $\mathrm{Cr}$ concentrations in various tissues. In a study conducted by Yoshida et al. [37], the different effects of $\mathrm{Cr}$ on $\mathrm{Cr}$ concentration in the liver, kidney and femur were the result of the dietary $\mathrm{Cr}$ level (1, $10,100 \mu \mathrm{g} \cdot \mathrm{g}^{-1} \mathrm{diet}$ ) than chemical form (CrPic vs. $\mathrm{CrCl}_{3}$ ). However, the greatest $\mathrm{Cr}$ concentration was found in kidneys, which was also confirmed in our study. Wang et al. [46] also reported that supplementary $\mathrm{Cr}$ at a dose of $200 \mu \mathrm{g} \cdot \mathrm{kg}^{-1}$ from CrNano and $\mathrm{CrPic}$ for 40 days increased the blood $\mathrm{Cr}$ level, $\mathrm{Cr}$ content in the liver, kidneys and heart as well as faeces and urine in finishing pigs. Different results were obtained by Clodfelder et al. [4], who found that 24-week supplementation with $\mathrm{Cr} 3$ at doses ranging from 250 to $1000 \mu \mathrm{g} \mathrm{Cr} \cdot \mathrm{kg}^{-1}$ diet did not increase the content of $\mathrm{Cr}$ in the liver and kidneys in healthy rats or the animals with type 2 diabetes. It is assumed that the absorption and utilisation of $\mathrm{Cr}$ depend on its status in the gastrointestinal tract [46].

Some authors [47-49] indicated that prolonged supplementation with $\mathrm{Cr}$ (III) compounds may have negative impact on the metabolism of $\mathrm{Fe}$ due to the fact that $\mathrm{Cr}$ and $\mathrm{Fe}$ are bound with the same protein-transferrin. Human serum transferrin $(\mathrm{Tf})$ is the iron transport protein responsible for delivering iron and a variety of other metals to cells [50]. This protein consists of two almost identical lobes, referred to as the $\mathrm{C}$-lobe and the $\mathrm{N}$-lobe, which can bind one metal ion each [51-53]. It was found that $\mathrm{Fe}^{3+}$ binding to the C-lobe is approximately 20 times stronger than $\mathrm{Fe}^{3+}$ binding to the $\mathrm{N}$ lobe. Trivalent chromium $\left(\mathrm{Cr}^{3+}\right)$ same for iron $\left(\mathrm{Fe}^{3+}\right)$ typically binds to the C-lobe first, followed by loading into the N-lobe. Under normal conditions, only approximately $30 \%$ of the potential $\mathrm{Fe}^{3+}$ binding sites in $\mathrm{Tf}$ are occupied, leaving the unoccupied binding sites in either the $\mathrm{C}$-lobe or the N-lobe, or both, to potentially bind other metal ions $[51,52] . \mathrm{Cr}^{3+}, \mathrm{Cu}^{2+}$, $\mathrm{Zn}^{2+}, \mathrm{Al}^{3+}, \mathrm{Ga}^{3+}, \mathrm{Ni}^{2+}$ and $\mathrm{Ti}^{4+}$ are known to bind to $\mathrm{Tf}$, and these metal ions could either compete with $\mathrm{Fe}^{3+}$ for $\mathrm{Tf}$ coordination or bind to the unoccupied lobes of $\mathrm{Tf}$ [54]. $\mathrm{Cr}^{3+}$ preferentially binds to the C-lobe of $\mathrm{Tf}$, suggesting that it has the potential to compete with $\mathrm{Fe}^{3+}$ for that binding pocket. When saturation of transferrin with iron increases to over $50 \%$, iron competes with chromium binding, affecting its transport [55]. The relationship between iron and chromium metabolism needs to be further investigated. It is not yet clear if chromium decreases iron absorption or if it is also involved in the downregulation of iron absorption [55]. It is also possible that exposure to high doses of $\mathrm{Cr}$ causes $\mathrm{Cr}^{3+}$ to bind to $\mathrm{Tf}$ and interferes with normal iron uptake, thus affecting Fe metabolism [1]. In case of oversupply of $\mathrm{Cr}$, it may reduce $\mathrm{Fe}$ transportation to the cells, wherein the $\mathrm{Cr}$-Fe interaction may occur already in the intestine, where these elements compete for a common site of absorption. A similar mechanism of interaction can also occur between supplementary $\mathrm{Cr} 3$ and $\mathrm{Zn}$ and $\mathrm{Cu}$, as the absorption of these elements is interdependent.

In our study, the blood morphological indices remained unchanged, which indicates that $\mathrm{Cr} 3$ did not affect erythropoiesis [27]. A lower Fe level in the serum and tissue stores (in the liver and kidneys) was noted, but these changes occurred only after the application of very high doses of $\mathrm{Cr}$ (III) (50 and $100 \mathrm{mg} \mathrm{Cr}(\mathrm{III}) \cdot \mathrm{kg}^{-1}$ b.m.). These results correspond to the study by Anderson et al. [47], who found a reduced Fe level in the tissues of rats supplemented with $\mathrm{CrCl}_{3}$. Also, Ani et al. [48] reported reduced transferrin saturation and tissue stores of $\mathrm{Fe}$ as well as lower haemoglobin and haematocrit index in rats fed a diet with a high dose of $\mathrm{Cr}(\mathrm{III})$.

Sun et al. [17] found that $\mathrm{Cr} 3$ administered to normal Sprague-Dawley (SD) rats at a dose of $20 \mu \mathrm{g} \cdot \mathrm{kg}^{-1}$ b.m. for 24 weeks did not have a significant effect on the liver and kidney $\mathrm{Fe}$ contents. However, they observed higher liver $\mathrm{Fe}$ 
Table 4 The effect high dietary doses of $\mathrm{Cr} 3$ on blood glucose concentration and lipid profile indices in female rat (mean $\pm \mathrm{SEM}$ ) [27]

\begin{tabular}{llllll}
\hline Index & \multicolumn{2}{l}{ Experimental groups } & & \\
\cline { 2 - 6 } & $\begin{array}{l}\text { Control } \\
\left(1 \mathrm{mg} \cdot \mathrm{kg}^{-1}\right)\end{array}$ & $\begin{array}{l}\mathrm{A} \\
\left(100 \mathrm{mg} \cdot \mathrm{kg}^{-1}\right)\end{array}$ & $\begin{array}{l}\mathrm{B} \\
\left(200 \mathrm{mg} \cdot \mathrm{kg}^{-1}\right)\end{array}$ & $\begin{array}{l}\mathrm{C} \\
\left(500 \mathrm{mg} \cdot \mathrm{kg}^{-1}\right)\end{array}$ & $\begin{array}{l}\mathrm{D} \\
\left(1000 \mathrm{mg} \cdot \mathrm{kg}^{-1}\right)\end{array}$ \\
\hline Glucose concentration $\left(\mathrm{mg} \mathrm{dl}{ }^{-1}\right)$ & $105.7 \pm 4.9$ & $98.7 \pm 8.6$ & $98.8 \pm 4.1$ & $92.5 \pm 2.5$ & $94.8 \pm 3.9$ \\
Total-cholesterol concentration $\left(\mathrm{mg} \mathrm{dl}^{-1}\right)$ & $61.5 \pm 8.4$ & $72.2 \pm 2.8$ & $67.0 \pm 5.5$ & $63.3 \pm 4.6$ & $64.3 \pm 2.6$ \\
LDL-cholesterol concentration $\left(\mathrm{mg} \mathrm{dl}^{-1}\right)$ & $4.67 \pm 0.49$ & $5.17 \pm 0.54$ & $5.17 \pm 0.54$ & $5.00 \pm 0.26$ & $5.17 \pm 0.87$ \\
HDL-cholesterol concentration $\left(\mathrm{mg} \mathrm{dl}^{-1}\right)$ & $39.8 \pm 3.6$ & $41.5 \pm 1.3$ & $39.8 \pm 1.8$ & $37.2 \pm 3.5$ & $38.8 \pm 1.0$ \\
TAG-triglycerides concentration $\left(\mathrm{mg} \mathrm{dl}^{-1}\right)$ & $30.7 \pm 1.9^{\mathrm{ab}}$ & $32.2 \pm 2.8^{\mathrm{ab}}$ & $37.0 \pm 3.0^{\mathrm{b}}$ & $25.2 \pm 2.4^{\mathrm{a}}$ & $25.3 \pm 2.6^{\mathrm{a}}$ \\
\hline
\end{tabular}

The values in the same row that do not share the same superscript letter are significantly different $(P<0.05)$

Control control group, $A$ group supplemented with $100 \mathrm{mg} \mathrm{Cr}(\mathrm{III}) \cdot \mathrm{kg}^{-1}$ diet, $B$ group supplemented with $200 \mathrm{mg} \mathrm{Cr}(\mathrm{III}) \cdot \mathrm{kg}^{-1}$ diet, $C$ group supplemented with $500 \mathrm{mg} \mathrm{Cr}(\mathrm{III}) \cdot \mathrm{kg}^{-1}$ diet, $D$ group supplemented with $1000 \mathrm{mg} \mathrm{Cr}(\mathrm{III}) \cdot \mathrm{kg}^{-1}$ diet

level and lower kidney Fe concentrations than their controls in Zucker obese (ZKO) rats [17]. Also, Love et al. [56] observed that the dietary $\mathrm{Cr}\left(16-2000 \mu \mathrm{g} \cdot \mathrm{kg}^{-1}\right.$ diet) given for 23 weeks had no effect on the blood iron level in Zucker lean (ZKL) rats. Similarly, Clodfelder et al. [4] did not observe adverse effects of $\mathrm{Cr} 3$ on the Fe status when given to healthy rats or to the animals with type 2 diabetes for 24 weeks as an aqueous solution at doses of $250-1000 \mu \mathrm{g}$ of $\mathrm{Cr} \cdot \mathrm{kg}^{-1} \mathrm{~b} . \mathrm{m}$. In contrast, $\mathrm{Cr} 3$ supplementary in doses 10 and $50 \mathrm{mg} \cdot \mathrm{kg}^{-1}$ diet for 8 weeks increased kidney $\mathrm{Fe}$ and spleen $\mathrm{Cu}$ contents but did not affect $\mathrm{Zn}$ status in rats fed with high-fat diet [33]. The studies by Shara et al. [38, 39] demonstrated that long-term supplementation with complex $\mathrm{Cr}$ (III) with niacin did not affect the metabolism of $\mathrm{Fe}$ in the rat (as assessed by the content of $\mathrm{Fe}$ in the serum, TIBC, RBC, haemoglobin and selected indicators of blood morphology). Prescha et al. [36] reported that supplementary $\mathrm{Cr}$ in a diet enriched with cellulose and/or pectin led to higher $\mathrm{Cr}$ and $\mathrm{Fe}$ contents in the femurs but did not change the Fe content in the liver, kidneys and muscles in male Buffalo rats.

Research on humans supplemented with $\mathrm{Cr}$ (III) at doses of 200-1000 $\mu \mathrm{g} \cdot \mathrm{day}^{-1}$ did not confirm significant effects on the Fe status. Campbell et al. [57] showed that 3-month supplementation of males aged 60-70 years with $\mathrm{Cr}(\mathrm{Pic})_{3}$ at an amount of $924 \mu \mathrm{g}$ of $\mathrm{Cr} \cdot$ day $^{-1}$ had no effect on the $\mathrm{Fe}$ status. Similarly, Lukaski et al. [58] did not observe any changes in haemoglobin, haematocrit, serum Fe content, TIBC or transferrin saturation in 83 premenopausal women supplemented with $\mathrm{Cr}(\mathrm{Pic})_{3}$ at a dose of $200 \mu \mathrm{g} \mathrm{Cr} \cdot$ day $^{-1}$. Volpe et al. [59] found that 12-week supplementation with $\mathrm{Cr}(\mathrm{Pic})_{3}$ at a dose of $400 \mu \mathrm{g} \cdot$ day $^{-1}$ combined with the exercise programme did not affect Fe or $\mathrm{Zn}$ levels in the serum of women with moderate obesity.

Anderson et al. [43] studied the effect of $\mathrm{Cr}(\mathrm{Pic})_{3}$ supplementation on the tissular levels of $\mathrm{Fe}, \mathrm{Zn}$ and $\mathrm{Cu}$ in pigs. They found that $\mathrm{Cr}$ did not affect the level of these elements in the liver and heart but caused an increase in the Fe content and decrease in $\mathrm{Zn}$ and $\mathrm{Cu}$ contents in the kidneys.
Pechova et al. [60] observed that the addition of $\mathrm{Cr}$ (III) in the form of chromium yeast $\left(5 \mathrm{mg} \cdot \mathrm{day}^{-1}\right.$ at the initial period of the experiment and increased to $8 \mathrm{mg} \cdot$ day $^{-1}$ after 136 days) increased the $\mathrm{Cu}$ content, reduced the $\mathrm{Mg}$ and $\mathrm{P}$ levels in the serum, but had no effect on the plasma $\mathrm{Zn}$ concentration in young bulls.

Amatya et al. [61] conducted a study on broilers fed diets supplemented with $200 \mu \mathrm{g} \mathrm{Cr} \cdot \mathrm{kg}^{-1}$ in the form of $\mathrm{CrCl}_{3}$ and yeast chromium for 21 and 35 days. They found that the $\mathrm{Cr}$ level in the liver was lower than in the control group, the $\mathrm{Cu}$ content increased in the blood serum and liver, while the $\mathrm{Fe}$ and $\mathrm{Mn}$ content decreased in the liver.

Dębski et al. [62] reported an increase in the $\mathrm{Cr}$ and $\mathrm{Cu}$ content, but no change in the $\mathrm{Zn}$ level in the livers of hens fed a diet enriched with chromium yeast $\left(0.5 \mathrm{mg} \cdot \mathrm{kg}^{-1}\right.$ dry mass $)$ for 2 months.

Sahin et al. [44] showed that supplementary $\mathrm{Cr}(\mathrm{Pic})_{3}(200$, 400, 800, $1200 \mu \mathrm{g} \mathrm{Cr} \cdot \mathrm{kg}^{-1}$ ) increased the $\mathrm{Cr}$ and $\mathrm{Zn}$ content but decreased the $\mathrm{Cu}$ level in the serum, liver, kidneys and muscles. The concentrations of $\mathrm{Fe}$ and $\mathrm{Mg}$ did not change in these tissues as dietary chromium supplementation was increased in the Japanese quail. Krejpcio et al. [63] found that supplementation with $\mathrm{Cr} 3$ (5 mg. $\mathrm{kg}^{-1}$ of diet) did not affect $\mathrm{Mg}$ levels in Wistar rats. Król et al. [64] showed that Cr3 supplementation disturb mineral homeostasis in the rats' organs fed high-fructose diet. $\mathrm{Cr} 3$ increased $\mathrm{Mg}, \mathrm{Cu}$ and $\mathrm{Cr}$ levels, although it did not influence tissular $\mathrm{Ca}, \mathrm{Fe}$ and $\mathrm{Zn}$ contents, given for 4 weeks in doses 1 and $5 \mathrm{mg} \cdot \mathrm{kg}^{-1}$ b.w. per day.

The addition of $\mathrm{Cr}$ (III) to the fibre-free diet and to the diets with cellulose or pectin did not change the $\mathrm{Zn}, \mathrm{Mg}$ and $\mathrm{P}$ contents in the femur and $\mathrm{Cr}, \mathrm{Fe}$, and $\mathrm{Zn}$ levels in the muscles in rats [36]. However, the addition of pectin or cellulose to the diets, especially with $\mathrm{Cr}$, increased the $\mathrm{Zn}$ content in the liver and kidneys and changed the $\mathrm{Mg}$ and $\mathrm{Ca}$ levels in these tissues [36].

Dogukan et al. [13] reported that supplementation with chromium histidinate (CrHis) increased the serum, liver, kidney $\mathrm{Cr}$ and $\mathrm{Zn}$ contents but decreased the $\mathrm{Cu}$ levels both in diabetic and non-diabetic rats. However, the serum, liver and kidney $\mathrm{Fe}$ concentrations were unchanged. In our previous 
studies [25], we observed that the $\mathrm{Cu}, \mathrm{Zn}, \mathrm{Fe}$ and $\mathrm{Mg}$ concentration in the liver of obese Zucker rats was lower than in ZDF and/or lean Zucker rats.

The role of $\mathrm{Cr}$ in the $\mathrm{Ca}$ of bone metabolism is unclear. $\mathrm{CrPic}_{3}$ has been found to reduce the urinary excretion of hydroxyproline and $\mathrm{Ca}$ in postmenopausal women, presumably indicating a reduced rate of bone resorption [65]. Evans et al. [65] observed reduced $\mathrm{Ca}$ excretion, an increased dehydroepiandrosterone level (DHEA) and reduced hydroxyproline to creatinine ratio in the urine of postmenopausal women after 60-day supplementation with $\mathrm{Cr}(\mathrm{Pic})_{3}$ at a dose of $200 \mu \mathrm{g} \cdot$ day $^{-1}$, suggesting that $\mathrm{Cr}$ (III) could effectively prevent osteoporosis.

In other studies, the liver $\mathrm{Ca}$ content in lean rats was significantly increased by $\mathrm{Cr} 3$ and $\mathrm{CrPic}_{3}$ when administered at $1 \mathrm{mg} \mathrm{Cr} \cdot \mathrm{kg}^{-1}$ b.m., but the Mg level was not affected [25]. Prescha et al. [36] showed that the liver Ca content was very sensitive to supplemental $\mathrm{Cr}$ when given together with pectin and cellulose to Buffalo rats.

This study showed that high doses of supplementary $\mathrm{Cr} 3$ (100-1000 $\mathrm{mg} \mathrm{Cr}(\mathrm{III}) \cdot \mathrm{kg}^{-1}$ of diet) reduced the Ca content in the rat liver in a dose-dependent manner. The research by Sankaramanivela et al. [66] revealed that the exposure of male Wistar rats to $\mathrm{K}_{2} \mathrm{Cr}_{2} \mathrm{O}_{7}$ at a dose of $0.5 \mathrm{mg} \cdot \mathrm{kg}^{-1}$ b.m. for 5 days increased the Ca content in the femur and cranial vault but reduced the activity of ALP and TRAP (resistant acid phosphatase tartrate), which the authors explained with low Ca resorption activity from the bone tissue.

The results of this experiment suggest that supplementary doses of $\mathrm{Cr} 3\left(100-1000 \mathrm{mg} \mathrm{Cr} \cdot \mathrm{kg}^{-1}\right.$ diet; eq. $\sim 10-$ $100 \mathrm{mg} \mathrm{Cr} \cdot \mathrm{kg}^{-1}$ b.m) given for 4 weeks did not affect the $\mathrm{Mg}$ status but influenced the $\mathrm{Cr}, \mathrm{Fe}, \mathrm{Zn}, \mathrm{Cu}$ and $\mathrm{Ca}$ levels in healthy female Wistar rats.

In conclusion, high dietary $\mathrm{Cr} 3$ supplementation may affect the mineral balance in rat tissues.

Compliance with Ethical Standards The experimental protocol was approved by the Local Bioethical Commission in Poznań (No. 12/2005).

Conflict of Interest The authors declare that they have no conflict of interest.

Open Access This article is distributed under the terms of the Creative Commons Attribution 4.0 International License (http:// creativecommons.org/licenses/by/4.0/), which permits unrestricted use, distribution, and reproduction in any medium, provided you give appropriate credit to the original author(s) and the source, provide a link to the Creative Commons license, and indicate if changes were made.

\section{References}

1. Cefalu WT, Hu FB (2004) Role of chromium in human health and in diabetes. Diabetes Care 27:2741-2751. doi:10.2337/diacare.27. 11.2741

2. Tang H, Xiao Q, Xu H, Zang Y (2015) Hypoglycemic activity and acute oral toxicity of chromium methionine complexes in mice. $\mathrm{J}$
Trace Elem Med Biol 29:136-144. doi:10.1016/j.jtemb.2014.07. 001

3. Sharma S, Agrawal RP, Choudhary M, Jain S, Goyal S, Agarwal V (2011) Beneficial effect of chromium supplementation on glucose, $\mathrm{HbA} 1 \mathrm{C}$ and lipid variables in individuals with newly onset type-2 diabetes. J Trace Elem Med Biol 25:149-153. doi:10.1016/j.jtemb. 2011.03.003

4. Clodfelder BJ, Gullick BM, Lukaski HC, Neggers Y, Vincent JB (2005) Oral administration of the biomimetic $\left[\mathrm{Cr}_{3} \mathrm{O}\left(\mathrm{O}_{2} \mathrm{CCH}_{2} \mathrm{CH}_{3}\right)_{6}\left(\mathrm{H}_{2} \mathrm{O}\right)_{3}\right]^{+}$increases insulin sensitivity and improves blood plasma variables in healthy and type 2 diabetic rats. $\mathrm{J}$ Biol Inorg Chem 10:119-130. doi:10.1007/s00775-004-0618-0

5. EFSA Panel on Dietetic Products, Nutrition and Allergies (NDA) (2014) Scientific opinion on dietary reference values for chromium: dietary reference values for chromium. EFSA J 12(10):3845. doi: 10.2903/j.efsa.2014.3845

6. Tinkov AA, Popova EV, Polyakova VS, Kwan OV, Skalny AV, Nikonorov AA (2015) Adipose tissue chromium and vanadium disbalance in high-fat fed Wistar rats. J Trace Elem Med Biol 29: 176-181. doi:10.1016/j.jtemb.2014.07.006

7. Vincent JB, Love ST (2012a) The need for combined inorganic, biochemical, and nutritional studies of chromium (III). Chemistry \& Biodiversity 9:2923-1941. doi:10.1002/cbdv.201100440

8. Institute of Medicine (U.S.) (2002) Dietary reference intakes for: vitamin a, vitamin $\mathrm{K}$, arsenic, boron, chromium, copper, iodine, iron, molybdenum, nickel, silicon, vanadium and zinc. In: A report of the panel of micronutrients, subcommittee on upper reference levels of nutrient and interpretations and uses of dietary reference intakes, and the standing committee on the scientific evaluation of dietary reference intakes. National Academy of Press, Washington DC IBSN 9780309072793 http://www.nap.edu

9. Sirirat N, Lu J-J, Hung AT-Y, Chen S-Y, Lien T-F (2012) Effects different levels of nanoparticles chromium picolinate supplementation on growth performance, mineral retention, and immune responses in broiler chickens. J Agricul Sci 4(12):48-58. doi:10. 5539/jas.v4n12p48

10. Laschinsky N, Kottwitz K, Freund B, Dresow B, Fischer R, Nielsen P (2012) Bioavailability of chromium (III) - supplements in rats and humans. Biometals 25:1051-1060. doi:10.1007/s10534-0129571-5

11. Shara M, Yasmin T, Kincaid AE, Limpach AL, Bartz J, Brenneman KA, Chatterjee A, Bagchi M, Stohs SJ, Bagchi D (2005a) Safety and toxicological evaluation of a novel niacin-bound chromium (III) complex. J Inorg Biochem 99:2161-2183. doi:10.1016/j. jinorgbio.2005.07.017

12. Shara M, Kincaid AE, Limpach AL, Sandstrom R, Barrett L, Norton N, Bramble JD, Yasmin T, Tran J, Chatterjee A, Bagchi M, Bagchi D (2007a) Long-term safety evaluation of a novel oxygen-coordinated niacin-bound chromium (III) complex. J Inorg Biochem 101:1059-1069. doi:10.1016/j.jinorgbio.2007.03. 015

13. Dogukan A, Sahin N, Tuzcu M, Juturu V, Onderci M, Komorowski J, Sahin K (2009) The effects of chromium histidinate on mineral status of serum and tissue in fat-fed and streptozotocin-treated type II diabetic rats. Biol Trace Elem Res 131:124-132. doi:10.1007/ s12011-009-8351-8

14. Tuzcu M, Sahin N, Orhan C, Ali Agca C, Akdmir F, Tuzcu Z, Komorowski J, Sahin K (2011) Impact of chromium histidinate on high fat diet induced obesity in rats. Nutrition \& Matabolism 8(28):1-8. doi:10.1186/1743-7075-8-28

15. Yang X, Palanichamy K, Ontko AC, Rao MN, Fang CX, Ren J, Sreejayan N (2005) A newly synthetic chromium complexchromium(phenylalanine) ${ }_{3}$ improves insulin responsiveness and reduces whole body glucose tolerance. FEBS Lett 579(6):1458 1464. doi:10.1016/j.febslet.2005.01.049 
16. Yang X, Li SY, Dong F, Ren J, Sreejayan N (2006) Insulinsensitizing and cholesterol-lowering effects of chromium ( $\mathrm{D}-$ phenylalanine $)_{3}$. J Inorg Biochem 100:1187-1193. doi:10.1016/j. jinorgbio.2006.01.039

17. Sun Y, Clodfelder BJ, Shute AA, Irvin T, Vincent JB (2002) The biomimetic $\left[\mathrm{Cr}_{3} \mathrm{O}\left(\mathrm{O}_{2} \mathrm{CCH}_{2} \mathrm{CH}_{3}\right)_{6}\left(\mathrm{H}_{2} \mathrm{O}\right)_{3}\right]^{+}$decreases plasma insulin, cholesterol and triglycerides in healthy and type II diabetic rats but not type I diabetic rats. J Biol Inorg Chem 7:852-862. doi:10. 1007/s00775-002-0366-y

18. Staniek H, Krejpcio Z, Iwanik K (2010a) Evaluation of the acute oral toxicity class of tricentric complex in rat. Food Chem Toxicol 48(3):859-864. doi:10.1016/j.fct.2009.12.022

19. Staniek H, Krejpcio Z, Iwanik K, Szymusiak H, Wieczorek D (2011) Evaluation of the acute oral toxicity class of trinuclear chromium (III) glycinate complex in rat. Biol Trace Elem Res 143(3): 1564-1575. doi:10.1007/s12011-011-8959-3

20. Li F, Wu X, Zou Y, Zhao T, Zhang M, Feng W, Yang L (2012) Comparing anti-hyperglycemic activity and acute oral toxicity of tree different trivalent chromium complexes in mice. Food Chem Toxicol 50:1623-1631. doi:10.1016/j.fct.2012.02.012

21. Institute of Medicine (2001) Dietary references intake for vitamin a, arsenic, born, chromium, copper, iodine, iron, manganese, molybdenum, nickel, silicon, vanadium, and zinc. National Academy Press, Washington, DC ISBN 10: 0-309-07279-4, DOI:10.17226/ 10026

22. Komorowski JR, Greengerg D, Juturu V (2008) Chromium picolinate does not produce chromosome damage. Toxicol in Vitro 22:232-234. doi:10.1016/j.tiv.2007.12.007

23. Stout MD, Nyska A, Collins BJ, Witt KL, Kissling GE, Malarkey DE, Hooth MJ (2009) Chronic toxicity and carcinogenicity studies of chromium picolinate monohydrate administered in feed to F344/ $\mathrm{N}$ rats and B6C3F1 mice for 2 years. Food Chem Toxicol 47(4): 729-733. doi:10.1016/j.fct.2009.01.006

24. Hepburn DD, Vincent JB (2003) Tissue and subcellular distribution of chromium picolinate with time after entering the bloodstream. J Inorg Biochem 94:86-93. doi:10.1016/s0162-0134(02)00623-2

25. Staniek H, Rhodes NR, Di Bona KR, Deng G, Love ST, Pledger LA, Blount J, Gomberg E, Grappe F, Cernosek C, Peoples B, Rasco JF, Krejpcio Z, Vincent JB (2013) Comparison of tissue metal concentrations in Zucker lean, Zucker obese, and Zucker diabetic fatty rats and the effects of chromium supplementation on tissue metal concentrations. Biol Trace Elem Res 151(3):373-383. doi:10.1007/ s12011-012-9565-8

26. Earnshaw A, Figgis BN, Lewis J (1966) Chemistry of polynuclear compounds. Part VI. Magnetic properties of trimeric chromium and iron carboxylates. J Chem Soc A:1656-1663

27. Staniek H, Krejpcio Z, Wieczorek D (2016) The effects of high dietary doses of chromium(III) complex with propionic acid on nutritional and selected blood indices in healthy female rats. Biol Trace Elem Res 171(1):192-200. doi:10.1007/s12011-015-0518-x

28. Staniek H, Kostrzewska-Poczekaj M, Arndt M, Szyfter K, Krejpcio Z (2010b) Genotoxicity assessment of chromium (III) propionate complex in the rat model using the comet assay. Food Chem Toxicol 48(1):89-92. doi:10.1016/j.fct.2009.09.020

29. Staniek H, Krejpcio Z (2009) The effects of tricentric chromium (III) propionate complex supplementation on pregnancy outcome and maternal and foetal mineral status in rat. Food Chem Toxicol 47:2673-2678. doi:10.1016/j.fct.2009.07.035

30. Clodfelder BJ, Upchurch RG, Vincent JB (2004a) A comparison of the insulin-sensitive transport of chromium in healthy and model diabetic rats. J Inorg Biochem 98:522-533. doi:10.1016/j.jinorgbio. 2004.01.003

31. Sun Y, Mallya K, Ramirez J, Vincent JB (1999) The biomimetic $\left[\mathrm{Cr}_{3} \mathrm{O}\left(\mathrm{O}_{2} \mathrm{CCH}_{2} \mathrm{CH}_{3}\right)_{6}\left(\mathrm{H}_{2} \mathrm{O}\right)_{3}\right]^{+}$decreases plasma cholesterol and triglycerides in rats: towards chromium-containing therapeutics. $\mathrm{J}$ Biol Inorg Chem 4:838-845 PMID: 10631616
32. Herring BJ, Logsdon AL, Lockard JE, Miller BM, Kim H, Calderon EA, Vincent JB, Bailey MM (2013) Long-term exposure to $\left[\mathrm{Cr}_{3} \mathrm{O}\left(\mathrm{O}_{2} \mathrm{CCH}_{2} \mathrm{CH}_{3}\right)_{6}\left(\mathrm{H}_{2} \mathrm{O}\right)_{3}\right]^{+}$in Wistar rats fed normal or highfat diets does not alter glucose metabolism. Biol Trace Elem Res 151(3):406-414. doi:10.1007/s12011-012-9580-9

33. Król E, Krejpcio Z, Iwanik K (2014) Supplementary chromium(III) propionate complex does not protect against insulin resistance in high-fat-fed diet. Biol Trace Elem Res 157:147-155. doi:10.1007/ s12011-013-9877-3

34. Bennett R, Adams B, Frech A, Neggers Y, Vincent JB (2006) Highdose chromium (III) supplementation has no effects on body mass and composition while altering plasma hormone and triglycerides concentrations. Biol Trace Elem Res 113:53-66. doi:10.1385/ BTER:113:1:53

35. Lewicki S, Zdanowski R, Krzyżowska M, Lewicka A, Dębski B, Niemcewicz M, Goniewicz M (2014) The role of chromium (III) in the organism and its possible use in diabetes and obesity treatment. Ann Agric Environ Med 21(2):331-335. doi:10.5604/1232-1966

36. Prescha A, Krzysik M, Zabłocka-Sowinska K, Grajeta H (2014) Effects of exposure to dietary chromium on tissue mineral contents in rats fed diets with fiber. Biol Trace Elem Res 159:325-331. doi: 10.1007/s12011-014-9973-Z

37. Yoshida M, Hatakeyama E, Hosomi R, Kanda S, Nishiyama T, Fukunaga K (2010) Tissue accumulation and urinary excretion of chromium in rats fed diet containing graded levels of chromium chloride or chromium picolinate. J Toxicol Sci 34(4):485-491. doi:10.2131/jts.35.485

38. Shara M, Yasmin T, Kincaid AE, Limpach A, Bartz J, Brenneman KA, Chatterjee A, Bagchi M, Stohs SJ, Bagchi D (2005b) Safety and toxicological evaluation of a novel niacin-bound chromium (III) complex. J Inorg Biochem 99:2161-2183. doi:10.1016/j. jinorgbio.2005.07.017

39. Shara M, Kincaid AE, Limpach AL, Sandstrom R, Barrett L, Norton N, Bramble JD, Yasmin T, Tran J, Chatterjee A, Bagchi M, Bagchi D (2007b) Long-term safety evaluation of a novel oxygen-coordinated niacin-bound chromium(III) complex. J Inorg Biochem 101:1059-1069. doi:10.1016/j.jinorgbio.2007.03.015

40. Clodfelder BJ, Chang C, Vincent JB (2004b) Absorption of the biomimetic chromium cation triaqua- $\mu_{3}-0 \times 0-\mu-$ hexapropioniatotrichromium(III) in rats. Biol Trace Elem Res 98: 159-170. doi:10.1385/BTER:98:2:159

41. Clodfelder BJ, Vincent JB (2005) The time-dependent transport of chromium in adult rats from the bloodstream to the urine. $\mathrm{J}$ Biol Inorg Chem 10:383-393. doi:10.1007/s00775-005-0647-3

42. Shute AA, Vincent JB (2002) The fate of the biomimetic cation triaqua- $\mu$-oxohexpropionatotrichromium (III) in rats. J Biol Inorg Chem 89:272-278. doi:10.1016/S01062-0134(02)00382-3

43. Anderson RA, Bryden NA, Evock-Clover CM, Steele NC (1997) Beneficial effects of chromium on glucose and lipid variables in control and somatotropin-treated pigs are associated with increased tissue chromium and altered tissue copper, iron, and zinc. J Anim Sci 75:657-661 PMID: 9078480

44. Sahin K, Sahin N, Kucuk O (2002) Effects of dietary chromium picolinate supplementation on serum and tissue mineral contents of laying Japanese quails. J Trace Elem Exp Med 15:163-169. doi:10. 1002/jtra.10013

45. Lindemann MD, Cromwell GL, Monegue HJ, Purser KW (2008) Effect of chromium source on tissue concentration of chromium in pigs. J Anim Sci 86:2971-2978. doi:10.2527/jas.2008-0888

46. Wang M-Q, Li H, He Y-D, Wang C, Tao W-J, Du Y-J (2012) Efficacy of dietary chromium(III) supplementation on tissue chromium deposition in finishing pigs. Biol Trace Elem Res 148:316321. doi:10.1007/s12011-012-9369-x

47. Anderson RA, Bryden NA, Polansky MN, Gaulscht K (1996) Dietary chromium effects on tissue chromium concentrations and chromium absorption in rat. J Trace Elem Exp Med 9:11-25. doi: 
10.1002/(SICI)1520-670X(199607)9:1<11::AID-JTRA2>3.0.CO; 2-K/abstract

48. Ani M, Moshtaghie AA (1992) The effect of chromium on parameters related to iron metabolism. Biol Trace Elem Res 32:57-64 PMID: 1375087

49. Preuss HG, Anderson RA (1998) Chromium uptake: examining recent literature 1997-1998. Curr Opin Clin Nutr Metab Care 1(6):509-512 PMID: 10565402

50. Chua AC, Graham RM, Trinder D, Olynyk JK (2007) The regulation of cellular iron metabolism. Crit Rev Clin Lab Sci 44:413-459. doi:10.1080/10408360701428257

51. Quarles CD, Brumaghim JL, Marcus RK (2010) Instrumental comparison of the determination of $\mathrm{Cr}^{3+}$ uptake by human transferrin. Metallomics 2:792-799. doi:10.1039/c0mt00032a

52. Quarles CD, Marcus RK, Brumaghim JL (2011) Competitive binding of $\mathrm{Fe}^{3+}, \mathrm{Cr}^{3+}$, and $\mathrm{Ni}^{2+}$ to transferrin. $\mathrm{J}$ Biol Inorg Chem 16: 913-921. doi:10.1007/s00775-011-0792-9

53. Vincent JB, Love S (2012b) The binding and transport of alternative metals by transferring. BBA 1820:362-378. doi:10.1016/j. bbagen.2011.07.003

54. Tinoco AD, Valentine AM (2005) Ti (IV) binds to human serum transferrin more tightly than does Fe (III). J Am Chem Soc 127: 11218-11219. doi:10.1021/ja052768v

55. Terpiłowska S, Siwicki AK (2012) The influence of chromium and iron on interleukin- $1 \alpha$ and interleukin- 6 concentration in vitro and in vivo. Centr Eur J Immunol 37(2):106-109 file://C:/Users/user/ Downloads/CEJOI_Art_18635-10\%20(1).pdf

56. Love ST, Di Bona KR, Shinha SH, McAdory D, Skinnner BR, Rasco JF, Vincent JB (2013) Urinary chromium excretion in response to an insulin challenge is not a biomarker for chromium status. Biol Trace Elem Res 152:57-65. doi:10.1007/s12011-0129594-3

57. Campbell WW, Beard JL, Joseph LJ, Evans WJ (1997) Chromium picolinate supplementation and resistive training by older men: effects on iron-status and hematologic indexes. Am J Clin Nutr 66(4): 944-949 PMID: 9322572
58. Lukaski HC, Siders WA, Penland JG (2007) Chromium picolinate supplementation in women: effects on body weight, composition and iron status. Nutrition 23:187-195. doi:10.1016/j.nut.2006.12. 001

59. Volpe SL, Huang HW, Larpadisorn K, Lesser II (2001) Effect of chromium supplementation and exercise on body composition, resting metabolic rate and selected biochemical parameters in moderately obese women following an exercise program. J Am Coll Nutr 20(4):293-306 PMID: 11506057

60. Pechová A, Illek J, Šindelar M, Pavlata L (2002) Effects of chromium supplementation on growth rate and metabolism in fattening bulls. Acta Vet Brno 71:535-541. doi:10.2754/avb200271010009

61. Amatya JL, Haldar S, Ghosh TK (2004) Effects of chromium supplementation from inorganic and organic sources on nutrient utilization, mineral metabolism and meat quality in broiler chickens exposed to natural heat stress. Anim Sci 79:241-253. doi:10. 1017/s135772980009010x

62. Dębski B, Zalewski W, Gralak MA, Kosla T (2004) Chromiumyeast supplementation of chicken broilers in an industrial farming system. J Trace Elem Med Biol 18(1):47-51. doi:10.1016/j.jtemb. 2004.02.003

63. Krejpcio Z, Wójciak RW, Staniek H, Wiśniewska J (2009) Effect of dietary supplementation with inulin-type fructans and chromium(III) on magnesium metabolic indices in rat. Zywnosc Nauka Technologia Jakosc 4(65):175-182 (in polish) pttz.org/ zyw/wyd/czas/2009,\%204(65)/22_Krejpcio.pdf

64. Król E, Krejpcio Z (2013) Dietary chromium(III) propionate complex supplementation affects tissue mineral levels in rats fed highfructose diet. J Elem 18(1):91-98. doi:10.5601/jelem.2013.18.1.07

65. Burckhardt P, Dawson-Hughes B, Heaney RP (2004) Aspects of osteoporosis, Second edn. Elsevier Academic Press, Amsterdam, Boston, pp 141-151 ISBN 0-12-14704-2

66. Sankaramanivel S, Jeyapriya R, Hemalatha D, Djody S, Arunakaran J, Srinivasan N (2006) Effect of chromium on vertebrae, femur and calvaria of adult male rats. Hum Exp Med 25:311318. doi:10.1191/0960327105ht627oa 